\title{
Temperature Controlled Aircraft Unit Load Devices:The Technological Response to Growing Global Air Cargo Cool Chain Requirements
}

\author{
Glenn Baxter', Kyriakos Kourousis²
}

\begin{abstract}
Unit load devices (ULDs) are pallets and containers which are used to carry air cargo, mail and passengers baggage on wide-body aircraft. Using an in-depth case study, an empirical investigation was undertaken to examine the recent technological developments and innovations in the temperature-controlled containers that are used extensively in the growing and highly important air cargo cool chains. The results demonstrated that advances in refrigeration systems and the use of composite materials used in the construction of these containers have enhanced the ability of key stakeholders to provide unbroken cool-chains. The study further demonstrated that the services and expertise of Envirotainer, the case company, as well as its strategic partnerships with key stakeholders, underpin its ability to deliver and capture value from its participation in the industry.
\end{abstract}

Keywords: air cargo; aircraft unit load devices; airlines; cool chain; temperature-controlled containers; wide-body aircraft

\footnotetext{
1,2 School of Aerospace, Mechanical and Manufacturing Engineering, RMIT University, GPO Box 2476V, Melbourne, Victoria, Australia 300I.

E-mail: 'glenn.baxter@rmit.edu.au (corresponding author).
} 


\section{Introduction}

Innovation initiatives are becoming exceptionally important for firms seeking greater competitiveness (Maldonado, Dias and Varvakis, 2009) as innovation is regarded as a key to success in many industries (Rothkopf and Wald, 2010). The factors driving innovation are manifold but are typically rooted in changes to the competitive environment of a company. A changing customer base, for example, may force firms to react by seeking new technological solutions. Technological changes (innovations) of a competitor will drive a firm to innovate. Furthermore, innovations can be driven by regulatory changes such as new regulations or by technological developments. Thus, regardless of the factors, innovations are a necessary precondition for firms to survive and remain ahead in every business (Rothkopf and Wald, 2010). In the global air transport industry an important area of technological advancement in recent times has been in aircraft unit load devices (ULDs). Unit load devices, or ULDs, are pallets and containers which are used to load passengers' baggage, air cargo and mail onto a wide-body aircraft (Lu and Chen, 20II; Baxter, Kourousis and Wild, 2014). The International Air Transport Association (IATA) estimates that there is currently around 700,000 ULDs in use by the world's airlines, with an estimated replacement value of close to approximately \$USDI billion (International Air Transport Association, 2013a).

Whilst much smaller in size than the passenger-side of the airline industry, the world air cargo industry has grown rapidly in recent decades and is now an integral part of the world economy, carrying around 35 per cent of the annual world merchandise trade by value (International Air Transport Association, 2014a). Air cargo is transported in the lower deck belly holds of combination passenger aircraft and by dedicated freighter aircraft (Oedekoven, 2010). Nearly 60 per cent of world air cargo traffic is carried in freighter aircraft (Boeing Commercial Airplanes, 2013) which are are operated by the integrators, such as FedEx and United Parcel Service (UPS), dedicated all-cargo carrying airlines, for example, Luxembourg-based Cargolux, and combination passenger airlines that operate freighter aircraft in addition to their scheduled passenger services, for instance, Cathay Pacific Airways or Korean Airlines. Most air cargo is carried in containers or ULDs, with the remainder transported loose in dedicated aircraft lower deck bellyhold compartments (Nobert and Roy, 1998).
The types of products transported by air cargo will vary on a route by route basis, but nonetheless some broad generalisations can be drawn. Globally, around one-third of total air cargo is composed of manufactured goods (Groups 6 and 8 in the Standard International Trade Classification [SITC]). Such goods include office equipment, computers, electronic products and components. A further third consists of machinery and transport equipment (SITC Group 7), which includes motor vehicle parts and components, construction machinery, communications equipment, and so forth. The final third or so compromises a variety of products, among which fresh food items and other agricultural produce, medical and pharmaceutical products and chemicals are quite significant (Doganis, 2009). The air cargo mode is especially important for high value goods requiring high speed transportation to markets. Such products require rapid transportation either because they are urgently required, or because they may otherwise perish or deteriorate when being transported over long distances (Oedekoven, 20I0; Shaw, 20II).

Air cargo enables shippers to ship highly perishable products to distant markets that cannot be serviced by highway or ocean transport. Sun, Chang and Oh (2012) define perishable cargo as goods that will deteriorate over a given period of time or some cargo that will deteriorate if exposed to adverse temperature, humidity, or other environmental conditions. Hence, the air cargo mode is used to ship a diverse range of perishable products such as high-value horticultural products including fruits, vegetables, flowers and fresh cut fruits and vegetables. Chilled and frozen meat, dairy products, fish and seafood are also commonly transported by the air cargo mode (Thompson, Bishop and Brecht, 2004). Such products require rapid transportation either because they are urgently required, or because they may otherwise perish or deteriorate when being transported over long distances (Oedekoven, 2010; Shaw, 20II). In addition, the market for healthcare products is continuing to grow around the world. An increasingly aging population needs access to new healthcare products and spending on national healthcare programs is a significant part of many government social policies. Speed to market is therefore critical and the healthcare industry is increasingly relying upon the air cargo mode (Gruber, 2012). The longer perishable products take to reach the customer, the more likely the product quality will decrease, which is why perishable products need to be delivered in a timely manner (Hoffman, 2012). Consequently, one of the biggest advances in the air cargo industry in recent times has been the development and use of innovative temperature controlled containers (Sales, 2013). 
The objective of this paper is to examine the recent technological response for temperature-controlled aircraft containers in global air cargo cool chains. To achieve this objective and to guide the empirical research conducted in the study, the following research questions were addressed:

- What have been the recent technological and technical innovations in temperature-controlled aircraft containers (ULDs) in response to the growing global air cargo cool-chain requirements?

- What role does the world's largest temperaturecontrolled aircraft container manufacturer play in the global air cargo cool chain?

The study compromises of five sections which include the introduction, a literature review, the research approach, in-depth case study, and conclusions. The literature review covers the role of aircraft ULDs in airline operations and in air cargo cool-chains as well as an overview of time and temperature management in air cargo transportation and this sets the context for the case study. The research methodology subsequently follows and presents the case study approach and the data collection sources and analysis method. The in-depth case study on Envirotainer is presented in the following section. The final section provides the concluding remarks on the research findings.

\section{The role of aircraft unit load devices in airline operations}

Dempsey and Gesell (1997) observe that "the technological beginning of the air cargo industry is rooted in the circumferential design of aircraft hulls" (p. 40I). As a by-product of the aeronautical design, space is created underneath the wide-body aircraft's main passenger deck where passenger baggage, postal mail and air cargo can be carried (Dempsey and Gesell, 1997).

With the introduction of wide bodied aircraft, such as the Boeing B747 and the McDonnell Douglas DCIO aircraft in the 1970s, a large volume of space was required to be filled in the lower deck belly holds of passenger flights and a faster method of loading and unloading needed to be introduced (Morrell, 20I la).Airlines therefore utilise special containers (aircraft unit load devices) that are designed to fit the lower deck belly holds of their wide-body passenger aircraft, together with specially designed containers to fit the main deck of their freighter aircraft (Baxter, 20 I I; Morrell, 20 I la). The utilization of ULDs assists airlines in the standardization and unitization of loading and discharging passenger baggage and air cargo at airports (Lu and Chen, 20I2).
In addition to the ULDs used to carry passenger baggage, airlines use special ULDs for the carriage of air cargo and mail, such as containers and pallets. An aircraft pallet and its net and/or igloo, and/or aircraft container, enable individual pieces of air cargo and passengers baggage to be assembled into a standard size unit to expedite the loading and unloading of aircraft (Allaz, 2004). The use of ULDs also protects the contents from damage and pilferage, and ensures the airline optimises the space inside the aircraft (O'Connor, 200I).

Airline ULDs have differing shapes that are designed to take into account the aircraft's curved contours (Wood, et. al., 1995). Airlines therefore select customized types of ULDs for matching the inner contours of the main and lower decks of various wide-bodied aircraft sizes. Since ULDs are also compatible with a variety of wide-body aircraft, airlines generally seek the benefit of commonality to purchase as many similar types of ULDs as possible (Lu and Chen, 20I2). In addition, because there are many different types of widebody passenger and freighter aircraft that carry cargo, as well as different possible configurations within the same aircraft type, most ULDs acquired by airlines are specific to a particular use (Chang, Son and Oh, 20l I).Thus each airline offers various types of containers/aircraft ULDs. These ULDs differ in tare weights, maximum weights, and volumes (Li, Tao and Wang, 2009).

The InternationalAirTransportAssociation (IATA) recognizes a set of standardized ULDs in the form of open pallets, igloos and ULD containers (International Air Transport Association, 20 I3b; Morrell, 20I la). Rigid bodied containers are used by airlines to protect air cargo (and passenger baggage) and to ease the handling of multiple small, individual consignments of air cargo. Pallets are devices providing a rigid base, suitable for forklifting, on which air cargo consignments can be loaded. The load is secured by nets, and the complete load can be manhandled, forklifted, or moved mechanically as a unit (Ashford, Mumayiz and Wright, 20I I). Similar to container ULDs, pallet size and shape/contour will vary on the aircraft operated by the airline (Reynolds-Feighan, 20I3). Igloos are rigid bodied pallets used principally to prevent damage to air cargo or to the interior of the aircraft, where passenger cabins are converted to all-cargo use. A structural igloo is a fully enclosed shell constructed integrally with a pallet base to ensure that cargo conforms to required contours. The shell and the pallet base form a single structural unit.A nonstructural igloo is a bottomless shell that fits over an aircraft pallet to provide shape to loaded cargo. The shell is used in conjunction with the aircraft pallet but does not provide any structural strength (Ashford, Mumayiz and Wright, 20ll). These ULDs are designed to be compatible with a number of aircraft types and are compatible with cargo terminal handling systems, the airport apron, and the aircraft loading equipment (Ashford, et al., 2013). 
The dimensions (and capacities) of the aircraft container ULDs used by the world's airlines depend on the aircraft flown and are often closed aluminium devices. Their size and shape depend on whether they are loaded onto lower or upper aircraft decks and whether they have been designed for use on narrow or wide-bodied aircraft (ReynoldsFeighan, 2013). For example, the Airbus A319, A320 and A32I aircraft offer airlines a containerised baggage/cargo system that saves on aircraft ground handling turnaround times (Airbus, 2013). Some airline ULDs are customised to fit a specific aircraft type, whereas others are compatible with multiple aircraft type. For instance, LD8 containers can only be utilised on Boeing B767 aircraft (Nobert and Roy, 1998), whereas LD9s can be used on Airbus A330, $A 340$ and $A 380$ as well as Boeing B777, 747 and 787 passenger aircraft. LD9s can also be used on Boeing MDI I, B777 and 747 freighter aircraft. Some containers/ ULDs are also temperature controlled (Reynolds-Feighan, 2013; Wood, et al., 1995).

Based on the requirements of Annex 6 (Aircraft operations, maintenance, and general aviation) and Annex 8 (Type design or manufacture of aircraft) to the 1944 Chicago Convention on International Civil Aviation (Waters, 2013a), the IATA ULD Regulations (ULDR) contains both technical and operational standard specifications and regulatory requirements as well as airlines requirements applicable to overall ULD operations. The ULD Regulations also provides the minimum standard specifications for designing and manufacturing ULDs that conform to IATA, International Organization for Standardization (ISO), SAE International, and other national and international standards (International Air Transport Association, 2013b).The regulations also relate to the various dimensions, material and other characteristics of airline ULDs as well as their registration, handling and maintenance (Chang, Son and Oh, 20I I).

\section{The air cargo cool chain}

Before briefly examining the air cargo cool chain it is important to note air cargo moves only because in so doing it provides value and competitive advantage - to the shipper, to the buyer, and to the third party service provider (3PSP). In the day-to-day commercial world the air cargo business of the participating industry actors is not conducted simply within marketplaces but also within corporately structured air cargo oriented chains and supply chains (Figure I); and all freight moves from buyer to seller in particular logistics and spatial pathways, of which airlines are but one element and are sustained by airline route networks. International airlines, cargo terminal operators, airline container manufacturers and freight forwarders like other, 3PSPs, deliver value to sellers, buyers, and dyadic partners embedded in the supply chain and expressed as a value proposition - and defined within the context of the firm's corporate strategic intent and strategies. All end-to-end freight movements, and in this context, international air cargo movements, may be conceptualised as chain structures involving transactional relationships between corporate actors in logistics pathways between buyers and sellers. 3PSPs are, in effect, elements in chains; and those chains are value driven air cargo chains (Robinson, 2009).

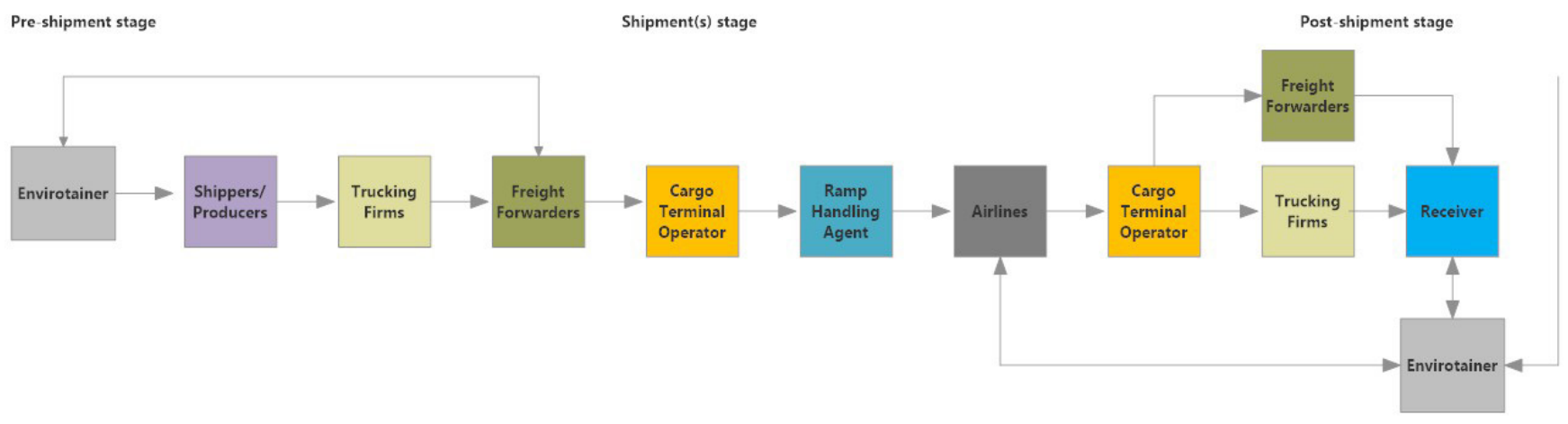

Figure. I. Hypothetical air cargo cool chain. Adapted from Baxter (20 I I), Harrison (20 I I).

ISSN: 07I 8-2724. (http://www.jotmi.org) 
The commercial life-span of certain products - for example, fresh fruit and vegetables, cut flowers, newspapers and magazines - is very short (Doganis, 2009). Thus, as previously noted, there are a range of products shipped by air cargo that require cool chain or temperature-sensitive transportation, including perishables such as cut flowers and foodstuffs. In recent years, the biggest cool-chain growth, however, has come from the health care sector (McPherson, 20I I; Waters 20I3b). Also, a critical factor for the air cargo industry is that food will not be purchased if it is considered unattractive by consumers, and in many countries around the world there are extremely stringent and rigorously enforced health and safety regulations which prohibits the sale of food in the first place if it does not conform to mandatory guidelines (Sales, 2013). Therefore the goods must be shipped as expeditiously as possible to the consumer, so as to avoid physical perishability or spoilage and to ensure the consumer receives the goods prior to the expiration of the goods commercial life (Morrell, 20llb). Physical perishability describes situations where the products being shipped physically deteriorate; exotic fruit and vegetables are examples of such products (Shaw, 20I I).Accordingly, the way that perishable products are transported successfully from their point-of-origin to the customer requires the use of specialised equipment, such as temperaturecontrolled ULDs, the application of considerable knowledge and expertise, and the implementation of a quality management system that permits the cool chain of and shipment to be analysed, controlled, measured, documented and validated (Sales, 20I3).

Maintaining a constant and unbroken temperaturecontrolled cool chain is, therefore, of critical importance in ensuring that the products being shipped in the supply chain remain fresh. The cold chain is a temperature controlled supply chain used to help extend and ensure the shelf-life of products being shipped (Coyle, et al., 20II).Critically, from the time that products are harvested at source by the grower or produced by a manufacturer to their arrival with the end-customer, the temperature of the products must not fluctuate beyond set parameters. Refrigerated vehicles (reefers), airport cargo terminals with cool rooms, insulated temperature-controlled aircraft ULDs, and various other specialised ground handling equipment, are used to transport consignments from cargo terminal to their designated aircraft. To help protect perishable consignments from the temperature extremes experienced in the transportation cycle, special packaging requirements are specified to ensure the freshness of the products, as well as to protect the aircraft from any damage arising from leaking boxes or shipper containers (Sales, 20I3).

Thus, in the perishables air cargo market segment, the characteristics associated with perishability such as refrigeration requirements assume great importance as does the requirement for careful handling due to the fragile nature of many physically-perishable products (Shaw, 1993).

\section{Temperature controlled aircraft unit load devices}

As noted earlier, one of the biggest advances in the global air cargo industry in recent times has been the development and use of temperature control containers (Sales, 20I3). Different versions of these containers are now available from the manufacturers, for example, C-Safe, a joint venture between AmSafe and AcuTemp of the United States or Sweden-based Environtainer ${ }^{\circ}$ (Figure 2) (Putzger, 20I2).
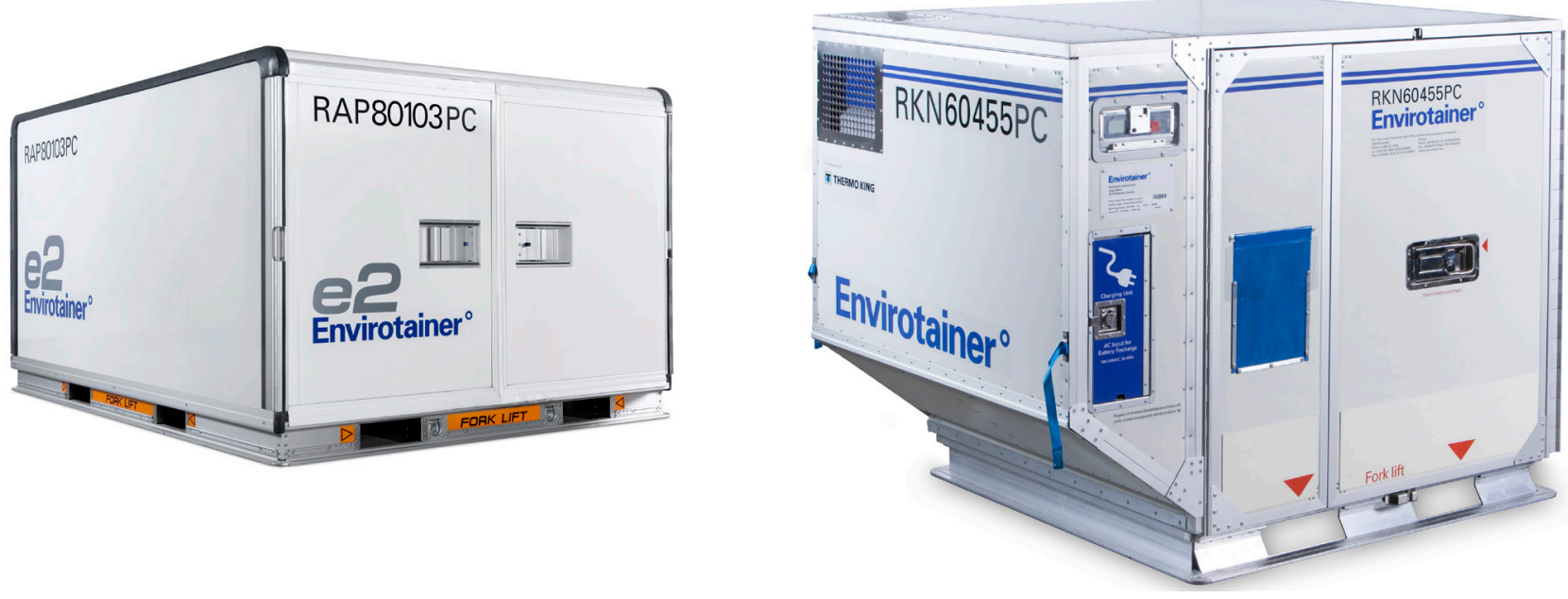

Figure. 2. Envirotainer ${ }^{\circ}$ active temperature-controlled containers (left: RAP e2, right: RKN). Source:"Envirotainer”.

ISSN: 07I 8-2724. (http://www.jotmi.org)

Journal of Technology Management \& Innovation @ Universidad Alberto Hurtado, Facultad de Economía y Negocios. 
Active temperature-controlled containers enable the transportation of commodities, both in the air and on the ground, thereby enhancing the life of temperaturesensitive commodities by preserving the cool chain throughout the complete life cycle of the end-to-end transportation process. These containers work by an active temperature-controlled system based on compressor cooling and electric heating equipment, or alternatively they use a temperature-controlled system based on dry ice refrigeration (Sales, 2013). Importantly, these containers are designed to be compatible on wide-body passenger and freighter aircraft types.

Many refrigerated products often require 2 to $8^{\circ} \mathrm{C}$ control during their transportation and storage (Williams, 2010). In order to meet this shipping requirement, special temperature-controlled containers (ULDs) have been developed that maintain a constant 2 to $8^{\circ} \mathrm{C}$ temperature throughout the shipment cycle. These are the most commonly used temperature-controlled containers used in the air cargo industry. There are also other special temperature-controlled containers that support a +15 ${ }^{\circ} \mathrm{C}$ to $+25{ }^{\circ} \mathrm{C}$ and $>-20{ }^{\circ} \mathrm{C}$ temperature ranges and these can be deployed for specialised transportation requirements (Sales, 20I3).

Temperature-controlled containers enable precise end-toend temperature control throughout every stage of the cold chain transportation cycle to ensure that the products being shipped inside is never affected by variable conditions experienced during the consignments journey (Sales, 20I3).

The key features for ensuring consistent temperature control contained in most commonly available standard temperature-sensitive airline containers are:

- Insulated container shell constructed in an allcomposite material for superior insulation properties;

- $\quad$ Full electric heating and compressor cooling system;

- Rechargeable batteries that can be charged at standard AC power connection points;

- Enhanced air circulation system inside the container ensuring a low temperature gradient within the entire cargo space;

- $\quad$ Air circulated by the heating and cooling unit is close to the set temperature;

- An easy-to-use control unit permits simple operation of the container;

- $\quad$ Fully validated recording solutions for temperature and battery information;

- $\quad$ They can be accessed from all sides by forklifts, even when fully loaded, eliminating the requirement for roller beds to move the containers in the warehouse and to and from trucking docks (Environtainer ${ }^{\circ}, 2014 a$; Sales, 20I3).
Temperature-controlled containers come in a range of sizes and technical specifications. Such containers are suitable for the transportation of all types of perishable products such as chilled meat, fish, fruits and vegetables, dairy products and pharmaceuticals. Furthermore, because each temperature-controlled container has its own mechanism by which the temperature parameters can be present, airlines are able to carry a wide range of products on the same flight (Sales, 2013).

\section{Time and temperature management in air cargo transportation}

The transportation of time-and-temperature sensitive products is a core service provided by IATA airlines and accredited freight forwarders or logistics service providers (Sales, 2013). Cathay Pacific Airways, for example, offers a "Fresh LIFT" product which provides specialised perishable shipment handling to facilitate and extend the shelf life of fresh products. The airline also offers a "Pharma LIFT" product which compromises a comprehensive range of specialised and professional air cargo services for temperature sensitive shipments designed to satisfy pharmaceutical shippers' requirements (Cathay Pacific Cargo, 20I3a, 20I3b).The IATA Perishable Cargo Regulations (PCRs) is an essential reference guide for all actors involved in the packaging and handling of temperature sensitive products for air transportation. This manual has been developed based on the experience of a number of the world's major airlines and the scientific data supplied by research institutions (International Air Transport Association, 20l4b).

Chapter 17 of the IATA Perishable Cargo Regulations titled "Air Transport Logistics for Time and Temperature Sensitive Healthcare Products" specifically addresses the temperature control management issues identified by the industry. The chapter details the requirements and standards for the transportation of time and temperature sensitive healthcare air cargo shipments, including the mandatory use of the Time and Temperature Sensitive label (Gruber, 2012; International Air Transport Association, 2014b). The Time and Temperature Sensitive label is an air cargo consignment label, specific to the healthcare industry, that must be affixed to all shipments booked as time and temperature sensitive cargo. Effective I July 20I2, the IATA Time and Temperature Sensitive label became a mandatory requirement for the transportation of healthcare cargo shipments (International Air Transport Association, 20 14c).

Technological solutions utilised for temperature monitoring and control have evolved since the introduction of temperature controlled ULDs. From the early 1980s the industry has increased its attention to the issues related to the effectiveness of such technological systems (Whalen,

ISSN: 07 I8-2724. (http://www.jotmi.org) 
1984). Primarily, strict timelines in the logistic cycle and market value of the pharmaceutical products has been the driver for technological innovation in this area (McDonald, 2009). Both refrigeration systems and devices monitoring the temperature in a transportation container, in this case ULDs, comprise of technologies providing cooling over a given period of time. This is achieved through advanced cooling systems and heat insulating materials, which are managed by a control system. Radio-frequency identification devices (RFID) and other state of the art innovations have also been successfully tested and implemented for active temperature control in ULDs (Laniel, Uysal and Emond, 20I I; Palafox-Albarran, Jedermann and Lang, 20l0). Nevertheless, the challenges associated with further expansion of this technology are not only of engineering (design and implementation) nature but mostly relate to the verification and compliance with the applicable standards and regulations.

\section{Research method}

With the aim of identifying and examining the recent innovations and technological development of temperaturesensitive containers in the global air cargo industry and their role in enhancing the transportation of perishable products and pharmaceuticals in air cargo cool chains, a qualitative research approach was used. The study of the temperaturesensitive containers in in air cargo cool chains is an emergent area of study. Thus, the most appropriate research method for such an emerging area is a qualitative method (Edmondson and McManus, 2007). A case study approach was used in this study as this allows for the exploration of complex phenomena (Eisenhardt, 1989; Yin, 2009). Furthermore, case study research enables the collection of rich, explanatory information (Mentzer and Flint, 1997) and permits researchers to build theory and connect with practice (McCutchen and Meredith, 1993).

In order to alleviate potential biases and to support measurement validity careful attention has been paid to the selection of sources used in the study (Fasone and Maggiore, 2012). Accordingly, data for the study was obtained from a range of documents, company materials available on the internet and records as sources of case evidence. Documents included corporate brochures, industry reports and press articles on the firms examined in the study. The study therefore used secondary data (Rahim and Baksh, 2003). The three principles of data collection as suggested by Yin (2009) were followed: the use of multiple sources of case evidence, creation of a database on the subject and the establishment of a chain of evidence.
The data collected in the study was analysed using content analysis. Content analysis is a research tool that can be utilised to determine the presence of certain concepts within texts. Texts can be broadly defined as books, articles, newspaper articles, historical documents as well as non-text based materials, such as television segments (Klenke, 2008). Content analysis procedures are used by researchers to describe, analyse and summarise trends and observations from field trips or the data that have been gathered (Green, 20II).

\section{Case analysis:Temperature controlled containers in the global air cargo industry}

The empirical results of the study's case study based on the world's major temperature-controlled aircraft container manufacturer - Envirotainer - is presented and discussed in this section.

\section{Envirotainer ${ }^{\circ}$}

\section{Company background and strategy}

Sweden-based cool chain logistics specialist Envirotainer ${ }^{\circ}$ is one firm playing a vital role in the transportation of perishable products and pharmaceuticals with its range of active temperature-controlled air cargo containers. The company rents these containers to users when they are required (Envirotainer ${ }^{\circ}, 2014 \mathrm{~g}$; Sales, 2013). Envirotainer was founded in 1985. In 1995, the company developed and marketed its first container with an active temperature control system (Envirotainer $\left.{ }^{\circ}, 2014 \mathrm{e}\right)$. The company's operations are international in nature and all production and development is undertaken in Tallbacksgatan I2, Rosersberg, which is located between Stockholm and Uppsala. In order to satisfy customer requirements, the firm have developed a global network of partners within the freight forwarding and airline industries, and has its own presence at most of the world's major airports. Envirotainer also has its own operations centres in Singapore, Dallas and Frankfurt (Envirotainer $\left.{ }^{\circ}, 2014 \mathrm{~g}\right)$.

During the second half of the 1990s, the company partnered with the world's leading air cargo-carrying airlines and has since then established a network of airline and forwarder partners for worldwide leasing services. Subsequently, Envirotainer's business strategy was sharpened and as a result, the firm's main focus now is on the healthcare and biotech industries (Envirotainer $\left.{ }^{\circ}, 2014 \mathrm{e}\right)$.

In 2006 Envirotainer instigated its QEP / CEP Training and Quality Program. This program acknowledges service providers that are capable of properly managing shipments using the company's containers (Envirotainer ${ }^{\circ}, 2014 \mathrm{e}$ ). 
Envirotainer now provides active temperature-controlled containers for use in air cargo transportation on a rent-itas required basis, through an open-platform global network. The company also provides other related services that ensure correct temperature throughout the transportation cycle - from loading to delivery. The temperature-controlled containers facilitates what the industry calls an "unbroken cold chain" (Envirotainer $\left.{ }^{\circ}, 2014 \mathrm{~g}\right)$. Envirotainer ${ }^{\circ}$ containers that have active temperature control are available in two sizes: RAP and RKN.

\section{Key target market: temperature-controlled ULDs for the pharmaceutical industry air cargo cool chain}

The change in market demographics and the greater accessibility and wider choice of drug products has led to continued demand for healthcare products around the world. Speed to market is therefore critical and the healthcare industry is increasingly relying upon air cargo to ship their products (Ramanujam, 2013). Global annual expenditure on pharmaceuticals is predicted to reach almost $\$ 1.2$ trillion U.S. dollars in 2016 (Freissmuth, 2013). The pharmaceutical industry markets drugs which are licensed for use as medications and it is in industry that relies extensively on air cargo to transport its raw products and carry its products to the end consumer (Sales, 20I3).

The pharmaceutical industry is continuing to undergo significant change as government regulations persist, blockbuster patents expire and the requirement for cost control increases in the industry. Consequently, there has been a move in the industry towards emerging markets for not just manufacturing but also penetration into expanding domestic markets (Air Cargo World, 20I3).
The requirement for temperature-controlled handling, storage and transportation is expanding as the growth of newly developed drugs, especially biopharmaceuticals and many clinical trials require such special handling (Air Cargo World, 2013). Handling and quality standards that are uniform across all stages of the supply chain are essential to ensure pharmaceutical products reach their destination in impeccable condition through an unbroken cool chain (Sales, 2013). The challenge of maintaining products at the correct temperature range so as to ensure the quality of the product is not affected in transit is therefore critical (Ramanujam, 2013).Temperature deviations and temperature excursions throughout the transportation cycle requires the establishment of a complete logistics process to maintain the shipment integrity (Ramanujam, 2013; Sales, 2013).

One of the most effective means to maintain the cool chain of products shipped by the air cargo mode is to use the active temperature-controlled ULDs (Sales, 2013). Active temperature-controlled ULDs are insulated containers with built-in refrigerated systems and include the means for temperature control. Most of the refrigeration system used in these containers are battery powered and often use dry ice as a refrigerant (Estrada-Flores, 20I2).

The active temperature-controlled containers are typically available for a rental period, thereby lowering shippers costs as they are only used as required and returned to the supplier when the lease is ended. The containers are subsequently cleaned, maintained and prepared in ideal conditions in preparation for use by the next customer (Sales, 2013).

\section{Mapping Envirotainer's role in air cargo cool-chains}

Figure 3 shows that the air cargo industry is comprised of a number of key stakeholders, which perform a range of complementary tasks in order to satisfy shippers' air cargo cool-chain requirements.

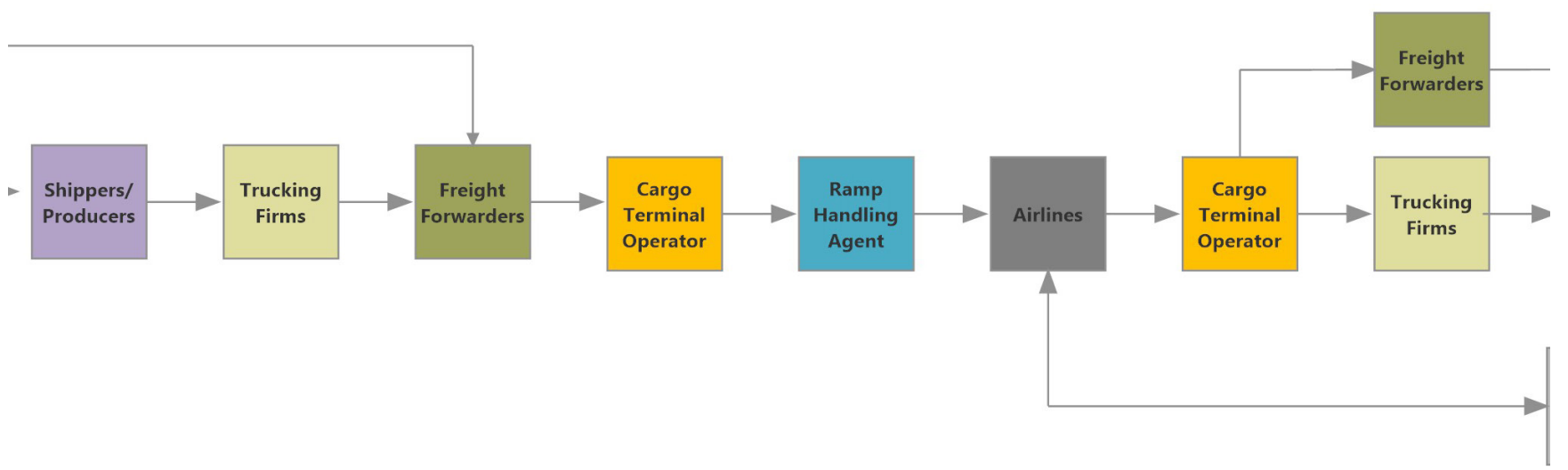

Figure. 3. Role of Envirotainer in a typical air cargo cool chain.Adapted from Baxter (20 I I), Harrison (20 I I).

ISSN: 07I 8-2724. (http://www.jotmi.org) 
-

Envirotainer

Envirotainer provides the temperature-controlled containers to customers on an as-required basis and supports this service with pre-shipment services (shipping qualifications), technical support and post-shipment services (post-shipment analysis) (adapted from Envirotainer, 2014f; Harrison, 20II). Envirotainer works with more than 400 companies within the pharmaceutical and healthcare industry (Envirotainer, 20l4g).

\section{- $\quad$ Shippers}

The shipper may be a company or an individual, exporting either general or perishable goods. The shipper, the owner of the goods, establishes the initial link in the air freight chain (The International Air Cargo Association, 1998). To ship their goods to a customer, a shipper will generally contact several freight forwarders to find cargo space and obtain the best price and service offered (Damsgaard, 1999).

- $\quad$ The trucking company's role

Trucking companies provide road transport services for producer/shippers transporting their products from their premises to their assigned freight forwarder (Fox, 20II) or to the airport where the consignments are handled and stored in preparation for their designated flight (Harrison, 20I I). The trucks used to satisfy shippers requirements are often refrigerated (Fox, 20l I) so as to sustain the cool-chain.

- International air freight forwarder

A freight forwarder is an agent who arranges the transportation of goods on behalf of others. Freight forwarders book cargo space for shippers, provide shipping documents, offer assistance in transportation logistics, including freight consolidation, customs brokerage, warehousing, distribution, and other value-added services and sometimes arrange other services such as shipment packing and cargo insurance (Corley, 2002). Having negotiated a contract with the shipper the freight forwarder then arranges for consignments to be packed ready for transport and subsequently tendered to the CTO for carriage. When the consignment is finally received at the destination freight forwarders often arrange the clearance and delivery to the consignee (Damsgaard, 1999).
- $\quad$ Cargo terminal operators (CTO)

The CTO controls the cargo at the airport. The air cargo terminal operator provides the handling facilities necessary to accept air freight consignments from international air freight forwarders and shippers; check shipment weights; and prepare aircraft load plans. They also store consignments until they have been cleared for export by customs or held in some cases for at least 24 hours at the terminal for safety reasons. At the destination, an air cargo terminal operator accepts cargo from incoming flights and stores the cargo until it has been cleared and released by the receiving country's customs authority (Damsgaard, 1999).

The CTO is usually contracted by each airline under an IATA Standard Ground Handling Agreement (SGHA) to provide handling services and therefore acts as the interface between their airline customers and freight forwarders/shippers.

- $\quad$ Ramp handling agent

When aircraft are on the ground in between flights they require various ground handling services to be performed, for example, aircraft loading/unloading; cargo handling; lavatory services, aircraft towing or pushback (Thompson, 2007). Operator personnel collect the freight from the CTO operator and are responsible for loading the cargo on to the correct aircraft. At the destination, they unload the aircraft and deliver the incoming consignments to the airline's contracted CTO's terminal (Damsgaard, 1999).

- $\quad$ Airlines

In the world air cargo industry there are three principal types of air cargo-carrying airlines: combination passenger airlines, dedicated all-cargo airlines, and the integrators. Combination airlines include airlines that provide both passenger and air cargo services, transporting air cargo in the lower deck belly holds of their passenger aircraft. Most international carriers fall into this category (Tretheway and Andriulaitis, 2010). Dedicated all-cargo airlines, such as Luxembourg-based Cargolux, carry air cargo only on an airport-to-airport basis and emphasize long-haul services. The integrators are firms that integrate the air and ground transport services traditionally performed by separate firms, for example, airlines and freight forwarders, to provide a full door-to-door service (Doganis, 2009). The largest integrators are FedEx, United Parcel Service (UPS), DHL and TNT Express. 
Thus, an airline provides transportation for air cargo consignments. On wide-body flights the consignments are loaded into special airline containers (ULDs) normally made of aluminium or on pallets (Damsgaard, 1999). Bazargan (20I0) notes that an airline's decision to operate certain flights will primarily depend on forecasted market demand, available aircraft operating characteristics, available manpower, regulations, and the behaviour of competing airlines.

\section{- Consignees}

The importer or consignee is the receiver of the goods. An importer may be a company or an individual.The importer is normally responsible for the destination processes, such as, customs clearance and product distribution (Victorian Air Freight Council, 1997).

\section{Technological advances in Envirotainer temperature-controlled containers}

In 2004, Envirotainer introduced cold chain management services, which included product validations in the company's own testing facilities, and qualifications in the field. The new RKN el electrical heating and compressor cooling container was launched in 2005. This container was developed and produced in collaboration with ThermoKing (Envirotainer $\left.{ }^{\circ}, 2014 \mathrm{e}\right)$.
Following EASA certification, the electrical heating and compressor cooling RAP e2 was introduced into service. This LD-9 size container was developed by the company's engineers, using a proprietary composite technology (Envirotainer ${ }^{\circ}, 2014 \mathrm{e}$ ) and the container's enhanced internal air circulation system ensures a low temperature gradient within the entire cargo space (Envirotainer ${ }^{\circ}, 2013 a$ ). Table I highlights the differences in Envirotainer's RKN and RAP temperature controlled containers. As can be observed from the table, the company has enhanced the refrigeration system in the RAP e2 and RKN el containers, which are now run on rechargeable batteries, which can last around 35 hours and can be charged at a standard AC-power outlet. These containers also have an insulated shell that helps to maintain the proper temperature during the transportation cycle (Hoffman, 2012). The Envirotainer ${ }^{\circ}$ RAP e2 container was designed for the most extreme requirements that are experienced by the healthcare industry when shipping their products to markets. The RAP e2 container maintains product temperatures in a number of discrete temperature ranges: the +2 to $+8^{\circ} \mathrm{C}$ range, controlled room temperature $\left(+15\right.$ to $\left.+25^{\circ} \mathrm{C}\right)$ range or at any chosen set temperature between \pm 0 and $+25^{\circ} \mathrm{C}$ in nearly any ambient condition (Envirotainer ${ }^{\circ}$,2013a). In contrast, the RAP t 2 container, which has a metal shell and uses dry ice as the refrigerant, provides accurate and reliable protection for large consignments of temperature-sensitive products (Envirotainer ${ }^{\circ}, 2014 a$ ).

Similar to the RAP E2, the RKN el container was also designed for the extreme requirements of the healthcare industry and also maintains product temperatures in several discrete ranges: the +2 to $+8^{\circ} \mathrm{C}$ range, in the controlled room temperature $\left(+15\right.$ to $\left.+25^{\circ} \mathrm{C}\right)$ range or at any chosen set temperature within the operating range of \pm 0 to $+20^{\circ} \mathrm{C}$ (Envirotainer ${ }^{\circ}, 2014 \mathrm{~b}$ ). The RKN el uses a different technology to the RKN t2 container; compressor cooling and electrical heating and has an insulated container shell (Envirotainer ${ }^{\circ}, 2013 b$ ). The Envirotainer ${ }^{\circ}$ RKN t2 container provides shippers with accurate and reliable protection for consignments of temperature-sensitive products. This container features Envirotainer's proven dry-icebased active temperature control system and enables the air transportation of both frozen and chilled products (Envirotainer $\left.{ }^{\circ}, 2014 d\right)$. 


\begin{tabular}{|c|c|c|c|c|}
\hline Key Characteristics & Envirotainer RKN & Envirotainer RAP & & \\
\hline & t2 & el & t2 & e2 \\
\hline $\begin{array}{l}\text { Refrigeration System } \\
\text { Type }\end{array}$ & $\begin{array}{l}\text { Thermostat con- } \\
\text { trolled heat exchanger } \\
\text { powered by } 16 \text { D-size } \\
\text { alkaline batteries } \\
\text { and using dry ice as } \\
\text { coolant }\end{array}$ & $\begin{array}{l}\text { Thermostat con- } \\
\text { trolled air condi- } \\
\text { tioning system with } \\
\text { compressor cool- } \\
\text { ing and electrical } \\
\text { heating. Powered } \\
\text { by rechargeable } \\
\text { batteries }\end{array}$ & $\begin{array}{l}\text { Thermostat con- } \\
\text { trolled heat ex- } \\
\text { changer powered by } \\
16 \text { D-size alkaline } \\
\text { batteries and using } \\
\text { dry ice as coolant }\end{array}$ & $\begin{array}{l}\text { Fully redundant } \\
\text { thermostat-con- } \\
\text { trolled air condi- } \\
\text { tioning system with } \\
\text { compressor cool- } \\
\text { ing and electrical } \\
\text { heating. Powered } \\
\text { by rechargeable } \\
\text { batteries }\end{array}$ \\
\hline $\begin{array}{l}\text { Maximum Cooling } \\
\text { Autonomy }\end{array}$ & $72 \mathrm{~h}$ & $>100 \mathrm{~h}$ & $72 \mathrm{~h}$ & $>100 \mathrm{~h}$ \\
\hline $\begin{array}{l}\text { Primary structure } \\
\text { material }\end{array}$ & Aluminium & Aluminium & Aluminium & Composites \\
\hline $\begin{array}{l}\text { Internal Dimensions } \\
\text { and Volume }\end{array}$ & \begin{tabular}{|l|}
$\mathrm{l}, 4 \mathrm{II} / \mathrm{I}, 355 / \mathrm{I}, 360 \mathrm{~mm}$ \\
$2.93 \mathrm{~m}^{3}$
\end{tabular} & $\begin{array}{l}, 340 / 1,319 / 1,3 / 5 \\
\mathrm{~mm} \\
2.30 \mathrm{~m}^{3} \\
\end{array}$ & $\begin{array}{l}3,170 / 2,230 / 1,620 \\
\mathrm{~mm} \\
8.22 \mathrm{~m}^{3}\end{array}$ & $\begin{array}{l}2,465 / 2,055 / \mathrm{I}, 260 \\
\mathrm{~mm} \\
6.38 \mathrm{~m}^{3}\end{array}$ \\
\hline Tare Weight & $265 \mathrm{~kg}$ & $635 \mathrm{~kg}$ & $450 \mathrm{~kg}$ & $1100 \mathrm{~kg}$ \\
\hline $\begin{array}{l}\text { Maximum net weight } \\
\text { of cargo }\end{array}$ & $1,323 \mathrm{~kg}$ & $\mathrm{I}, 538 \mathrm{~kg}$ & $5,583 \mathrm{~kg}$ & $4,933 \mathrm{~kg}$ \\
\hline $\begin{array}{l}\text { Cooling Tempera- } \\
\text { ture Range (desired } \\
\text { temperature inside } \\
\text { container) }\end{array}$ & -20 to $+20^{\circ} \mathrm{C}$ & \pm 0 to $+20^{\circ} \mathrm{C}$ & -20 to $+20^{\circ} \mathrm{C}$ & \pm 0 and $+25^{\circ} \mathrm{C}$ \\
\hline Forkliftable & Yes & Yes & Yes - empty only & Yes \\
\hline
\end{tabular}

Table I. Comparison of RAP e2/ RAPt2 and RKN el/ t2 containers: Summary of key characteristics and specifications Source: Envirotainer (20I3a, 20I3b, 20I4a, 20I4b, 20I4c, 20I4d). 


\section{Interchangeability of the Envirotainer ${ }^{\circ}$ temperature-controlled containers}

As noted earlier, airline ULDs are designed to be carried on different wide-body passenger and freighter aircraft. Table 2 shows that the Envirotainer ${ }^{\circ} \mathrm{RAP}$ e 2 and $\mathrm{RKN}$ el containers are interchangeable between a range of wide-body aircraft operated by the world's combination airlines, dedicated allcargo airlines and the integrators.

\begin{tabular}{|l|l|}
\hline Aircraft Manufacturer & Aircraft Models \\
\hline Airbus & A300, A3 I0,A330,A340,A380 \\
\hline Boeing & B747, B767, B777, MDI I' \\
\hline Ilyushin & IL86 \\
\hline Lockheed & LI0II \\
\hline McDonnell-Douglas' & DCI 0, MDII \\
\hline
\end{tabular}

Table 2. Envirotainer ${ }^{\circ}$ RAP e2 and RKN el containers aircraft compatibility.

Source: Envirotainer (20I3a, 20 I3b, 20I4a, 20I4b, 20I4c, 20I4d). Note: Boeing Commercial Airplanes acquired McDonnell-Douglas in 1997 (Senguttvan, 2006). The MDI I was originally produced by McDonnell-Douglas.

\section{SWOT analysis of the Envirotainer ${ }^{\circ}$ temperature- controlled containers}

Table 3 presents a SWOT analysis of the Envirotainer ${ }^{\circ}$ RAP e2 and RKN el containers in terms of the technological and innovation penetration of the market. SWOT analysis is the process of analyzing firms and their environments based on their strengths, weaknesses, opportunities and threats (Ahmed and Almarri, 2007).

This analysis summarizes and highlights the pros and cons of technological innovation and can be used a starting point for further investigation in this area. (Table 3).

\section{Strengths}

Largest temperature-controlled aircraft container company Quality of services and product which are in alignment with the user requirements

New technology ensures efficient cool chain management and unbroken cool chains

Enhanced product durability, due to the use of advanced materials

Enhanced handling capability (fork-liftable containers)

Global presence and capability of manufacturing - support companies

Relationships with key industry stakeholders

Extensive experience and expertise

\section{Opportunities}

Capability to cover emerging markets, for example, South America

Increased outreach of perishable medical supplies in hard to reach geographically dispersed areas

Opportunities for other value added perishables, such as local products, for example, chilled salmon

Globalisation of the pharmaceutical industry

Ageing of the world population and advances in pharma-

ceuticals for treatment

\section{Weaknesses}

Conventional ULDs are potentially more expendable compared to advanced ULDs Repair and support cost unknown

Acquisition cost is high

Complexity requires specialised labour and technical know-how which may remain with the manufacturer Uni-directional nature of air cargo traffic (Vega, 2008), could pose re-positioning issues for the containers

\section{Threats}

Advances in maritime containers technology and cheaper ocean freight costs could result in firms switching from air to ocean transport modes

Reliance upon the pharmaceutical sector growth - may be affected by external factors

New ULD manufacturers could enter the market 


\section{Conclusions}

The world air cargo industry has grown rapidly in recent decades and is now an integral part of the world economy. The types of commodities/products shipped by the air cargo mode are heterogeneous in nature. However, the pharmaceutical and life-science products have been one of the few commodity types that have shown consistent air cargo growth in recent years (Waters, 2013b). Consequently, the global air cargo industry is moving its focus to highervalue commodities such as the life sciences industry (Payload Asia 2014).The industry has responded to this opportunity with the development and use of innovative temperaturecontrolled containers. The study showed that Envirotainer, the world's largest temperature controlled container manufacturer and service provider, has strategically responded to the growing air cargo cool chain requirements, and now provides temperature-controlled containers that can be used for the carriage of pharmaceuticals, a high growth area, as well as the traditional perishable cargoes, such as chilled meat. The firm has very successfully innovated with its temperature-controlled cargo containers and by developing enhanced refrigeration systems and using stateof-the art composite materials the company's RAP el and RKN e 2 containers are able to be utilised so as to ensure an unbroken cool chain. In addition, to the deployment of these new technologies the company has plays a key role in air cargo cool chain by providing their containers on an 'as-required' basis and through strategic partnerships with key stakeholders and dedicated operations centres at key airports, which underpin air cargo cool chain operations. Strategic partnerships with major airlines and freight forwarders add to the firm's value proposition.

\section{Acknowledgments}

The authors would like to express their sincere gratitude to Envirotainer for their permission to include the image of their containers in this paper.

\section{References}

AHMED, A.M., Almarri, K.S. (2007). SWOT analysis for Air China. http://www.emeraldinsight.com/learning/ management_thinking/articles/pdf/air_china.pdf?PHPSESSID $=$ tn5uvca64v0ngt3cjpgoctji20 [Accessed January 28, 20I4].

AIR CARGO WORLD. (2013). Pharma market: poised for growth. Air Cargo World, 16(I), 32-35.

AIRBUS. (2013). A320 family: the market leader. http:// www.airbus.com/fileadmin/media_gallery/files/brochures_ publications/aircraft_families/A320_Family_market_leaderleaflet.pdf [Accessed January I, 2014].

ALLAZ, C. (2004). History of Air Cargo and Mail from the 18th Century. Christopher Foyle Publishing in association with The International Air Cargo Association, London.

ASHFORD, N.J., Mumayiz, S.A., Wright, P.H. (20I I). Airport Engineering: Planning, Design, and Development of 21 st Century Airports (4th ed.). John Wiley \& Sons, Hoboken, NJ.

ASHFORD, N.J., Stanton, H.P.M., Moore, C.A., Coutu, P., Beasley, J.R. (20I3). Airport Operations (3rd ed.). McGrawHill, New York.

BAXTER, G.S. (20II). Restructuring Air Freight Chains: Strategic Options for Competitive Advantage (unpublished $\mathrm{PhD}$ thesis). Griffith University, Brisbane, Australia.

BAXTER, G., KOUROUSIS, K.,WILD, G. (2014). Fire Resistant Aircraft Unit Load Devices and Fire Containment Covers:A New Development in the Global Air Cargo Industry. Journal of Aerospace Technology and Management, 6 (2), 202-209.

BAZARGAN, M. (2010). Airline Operations and Scheduling (2nd ed.). Ashgate Publishing, Farnham, UK.

BOEING COMMERCIAL AIRPLANES. (2013). World air cargo forecast 2012-2013. http://www.boeing.com/assets/ $\mathrm{pdf} /$ commercial/cargo/wacf.pdf [Accessed 23 December 20I3].

CATHAY PACIFIC CARGO. (20I3a). Products and solutions: Fresh LIFT. http://www.cathaypacificcargo.com/Default. aspx?tabid=610 [Accessed December 20, 2013].

CATHAY PACIFIC CARGO. (20I3b). Products and solutions: Pharma LIFT. http://www.cathaypacificcargo.com/en-us/ productssolutions/specialcargo/pharmalift.aspx [Accessed December 20, 20I3].

ISSN: 07 I8-2724. (http://www.jotmi.org) 
CHANG, Y.S., Son, M.G., Oh, C.H. (20II). Design and implementation of RFID based air-cargo monitoring system. Advanced Engineering Informatics, 25(I), 4I-52. http:// dx.doi.org//0.1016/j.aei.2010.05.004

CORLEY, W. (2002). Trade logistics I0I: an introduction to forwarding. Export America, 3(8), 16-18.

COYLE, J.J., Novack, R.A., Gibson, B.J., Bardi, E.J. (20II), Transportation:A Supply Chain Perspective (7th ed.). SouthWestern Cengage Publishing, Mason, $\mathrm{OH}$.

DAMSGAARD, J. (1999). Global Logistics System Asia Co., Ltd. Journal of Information Technology, I4(3), 303-3।4.

DEMPSEY, P.S., Gesell, L.E. (1997). Air Transportation: Foundations for the 21 st Century. Coast Aire Publications, Chandler, AZ.

DOGANIS, R. (2009). Flying off Course: Airline Economics and Marketing (4th ed.). Routledge, London.

EDMONDSON, A.C., McManus, S.E. (2007). Methodological fit in management field research. The Academy of Management Review, 32(4), I I55-II 79.

EISENHARDT, K.M.(1989). Building theories from case study research. Academy of Management Review, I4(4), 532-550.

ENVIROTAINER ${ }^{\circ}$ (2013a). Technical specifications: Envirotainer ${ }^{\circledR}$ container RAP e2. http://www.envirotainer. com/Documents/Downloads/Technical\%20Specifications/ Envirotainer_TechSpecRAPe2.pdf [Accessed January 23, 2014].

ENVIROTAINER'. (20I3b). Technical specifications: Envirotainer ${ }^{\circledR}$ container RKN el. http://www.envirotainer. com/Documents/Downloads/Technical\%20Specifications/ Envirotainer_TechSpecRKNel.pdf [Accessed January 23, 2014].

ENVIROTAINER ${ }^{\circ}$. (20I4a). Envirotainer RAP e2 container. http://www.envirotainer.com/en/active-containers/OurContainer-Products/Envirotainer-RAP-e2/] [Accessed January 29, 20I4].

ENVIROTAINER ${ }^{\circ}$. (20I4b). Envirotainer RKN el container. http://www.envirotainer.com/en/active-containers/OurContainer-Products/Envirotainer-RKN-el/] [Accessed January 29, 2014].
ENVIROTAINER ${ }^{\circ}$. (20I4c). Envirotainer RAP t2 container. http://www.envirotainer.com/en/active-containers/OurContainer-Products/Envirotainer-RAP-t2/] [Accessed January 29, 2014].

ENVIROTAINER ${ }^{\circ}$. (20I4d). Envirotainer RKN t2 container. http://www.envirotainer.com/en/active-containers/OurContainer-Products/Envirotainer-RKN-t2/ [Accessed January 29, 2014].

ENVIROTAINER ${ }^{\circ}$. (20I4e). History of Envirotainer. http:// www.envirotainer.com/en/top-About-us/History/ [Accessed January 23, 2014].

ENVIROTAINER ${ }^{\circ}$. (20I4f). Technical support. http://www. envirotainer.com/en/Active-Cold-Chain-Services/Technicalsupport/ [Accessed January 29, 20I4].

ENVIROTAINER . (20I4g). What we do. http://www. envirotainer.com/en/top-About-us/Our-Promise/ [Accessed January 23, 2014].

ESTRADA-FLORES, S. (2012).Transportation of frozen foods. In:Sun, D.W. (Ed.), Handbook of Frozen Food Processing and Packaging (2nd ed.). CRC Press, Boca Raton, FL, Pp. 217-234.

FASONE, V., Maggiore, P. (20I2). "Non-Aviation" activities and the introduction of new thinking and ideas in the airport business: Empirical evidence from an Italian case study. Journal of Airline and Airport Management, 2(I), 3450. http://dx.doi.org//0.3926/jairm.3

FOX, M.C. (20II). Disintegrative Power Structures in Australian Export Airfreight Chains (Unpublished PhD thesis). Griffith University, Brisbane, Australia.

FREISSMUTH, J. (20I3). Facing the pharmaceutical future. http://www.pharmamanufacturing.com/articles/2013/02 I/ [Accessed 22 December 2013].

GREEN, R.A. (20II). Case Study Research: A Program Evaluation Guide for Librarians. ABC-CLIO, Santa Barbara, CA.

GRUBER, A. (20I2). IATA standards: transportation of time and temperature sensitive products. http://www. pharmoutsourcing.com/Featured-Articles/I I 7703-IATAStandards-Transportation-of-Time-and-TemperatureSensitive-Products/ [Accessed December 22, 2013]

HARRISON, D. (20II). The Active Cold Chain. http://www. uldcare.com/DATA/DOCUMENT/Miamil I_THE_ACTIVE_ COLD_CHAIN_by_Donald_Harrison_Envirotainer.pdf [Accessed January 29, 2013] 
HOFFMAN, M. (20I2). Shipping perishables by air cargo, Food Logistics, March 16 [online]. http://www.foodlogistics. com/article/ I 06574 I I/shipping-perishables-by-air-cargo [Accessed December 2I, 2013]

INTERNATIONAL AIR TRANSPORT ASSOCIATION. (20I3a). ULD update, January 20/3. http://www.iata.org/ publications/tracker/jan-2013/Pages/ULDR.aspx [Accessed December 5, 20I3].

INTERNATIONAL AIR TRANSPORT ASSOCIATION. (2013b). IATA ULD regulations. IATA: Montreal.

INTERNATIONAL AIR TRANSPORT ASSOCIATION. (20/4a). Air cargo: Delivering the modern world, http:// www.iata.org/whatwedo/cargo/pages/index.aspx [Accessed January 12, 20I4].

INTERNATIONAL AIR TRANSPORT ASSOCIATION. (20I4b). Perishables \& pharma. https://www.iata.org/ whatwedo/cargo/pharma/pages/index.aspx [Accessed January 2I, 2014]

INTERNATIONAL AIR TRANSPORT ASSOCIATION. (20/4c). Time \& temperature sensitive label. https://www. iata.org/whatwedo/cargo/pharma/Pages/time-temperaturelabel.aspx [Accessed December 22, 2013]

KLENKE, K. (2008). Qualitative Research in the Study of Leadership. Emerald Group Publishing, Bingley, UK.

LANIEL, M., Uysal, I., Emond, J.P. 20II. Radio frequency interactions with air cargo container materials for real-time cold chain monitoring. Applied Engineering in Agriculture, 27(4), 647-652.

LI, Y., Tao, Y., Wang, F. (2009). A compromised large-scale neighborhood search heuristic for capacitated air cargo loading planning. European Journal of Operational Research, 199(2), 553-560. http://dx.doi.org//0.1016/j.ejor.2008.1I.033

LU, H.A., Chen, C.Y. (20II). A time-space network model for unit load device stock planning in international airline services. Journal of Air Transport Management, I7(2), 94- 100. http://dx.doi.org//0.1016/j.jairtraman.2010.09.004

LU, H.A.; Chen, C.Y. (20I2). Safety stock estimation of unit load devices for international airline operations. Journal of Marine Science and Technology, 20(4), 43I-440.
MALDONADO, M.U., Dias, N., Varvakis, G. (2009). Managing innovation in small high-technology firms: a case study in Brazil. Journal of Technology Management \& Innovation, 4(3), I30-I42. http://dx.doi.org/I0.4067/S07 I827242009000200011

McCUTCHEN, D.M., Meredith, J.R. (1993). Conducting case study research in operations management. Journal of Operations Management, II (3), 239-256. http://dx.doi. org//0.1016/0272-6963(93)90002-7

McDONALD, A. (2009). Shipping systems. European Pharmaceutical Contractor, March, I04-I07.

McPHERSON, K (20II) Air cargo \& the cold chain, World Trade 100, June. http://www.worldtradewt $100 . \mathrm{com} /$ articles/8733I-industry-update-air-cargo-and-the-cold-chain [Accessed December 20, 2013].

MENTZER, J.T., Flint, D.J. (1997). Validity in logistics research. Journal of Business Logistics, I8(I), 199-2I6.

MORRELL, P.S. (20l la). Moving Boxes by Air:The Economics of International Air Cargo. Ashgate Publishing, Farnham, UK.

MORRELL, P.S. (20I Ib). The air cargo industry. In: O'Connell, J.F.,Williams, G. (Eds.),Air Transport in the 2 I st Century: Key Strategic Developments. Ashgate Publishing, Farnham, UK, Pp. 235-25I.

NOBERT, Y., Roy, J. (1998). Freight handling personnel scheduling at air cargo terminals. Transportation Science, 32(3), 295-30I.

O'CONNOR, W.E. (200I). An Introduction to Airline Economics (6th ed). Praeger Publishers, Westport, CT.

OEDEKOVEN, M. (20I0).Air cargo management. In:Wald,A., Fay, C., Gleich, R.(Eds.), Introduction to Aviation Management. LIT Verlag, Münster, Germany, pp. 3 I I-327.

PALAFOX-ALBARRAN, J., Jedermann, R., Lang, W. (20I0). Prediction of temperature inside a refrigerated container in the presence of perishable goods, In ICINCO - Proceedings of the 7th International Conference on Informatics in Control, Automation and Robotics, Funchal, Portugal, I5-I8 June, I, 20-27.

PAYLOAD ASIA. (2014). Cold chain capabilities grow as market diversifies. Payload Asia, 30(I), 20. 
PUTZGER,I.(20I2).Just the tonic,Airline Cargo Management, II [Online]. http://www.airlinecargomanagement. $\mathrm{com} /$ feature/pharmaceuticals-supply-chain?session id=jiq8rrvchai5q2ev558hj8p914 [Accessed December 20, 2013].

RAHIM, A.R.A., Baksh, M.S.N. (2003). Case study method for new product development in engineer-to-order organizations. Work Study, 52(I), 25-36. http://dx.doi. org/I0.I I08/004380203/0458705

RAMANUJAM,V. (20I3). Pharma transport by air: delivering the modern world. ACAAI News, 4(3), 9-II.

REYNOLDS-FEIGHAN, A. (20I3). Comparative analysis of air freight networks in regional markets around the globe. In: Bookbinder, J.H. (Ed.), Handbook of Global Logistics: Transportation in International Supply Chains. Springer Science+Business Media, New York, pp. 324-366.

ROBINSON, R. (2009). Chain Systems Analysis: New Thinking about Supply Chain Efficiency. Monograph I. The Centre for Integrated Freight Systems Management, Melbourne, Australia.

ROTHKOPF, M., Wald, A. (20I0). Innovation in the airline business. In: Wald, A., Fay, C., Gleich, R. (Eds.), Introduction to Aviation Management. LIT Verlag: Münster, Germany, PP. 357-373.

SALES, M. (2013). The Air Logistics Handbook: Air Freight and the Global Supply Chain. Routledge, London.

SENGUTTVAN, P.S. (2006). Fundamentals of Air Transport Management. Excel Books: New Delhi.

SHAW, S. (1993). Effective Air Freight Marketing. Hyperion Books, London.

SHAW, S. (20II). Airline Marketing and Management (7th ed.). Ashgate Publishing, Farnham, UK.

SUN, M.G., Chang, Y.S., Oh, C.H. (20I2). Smart perishable cargo management with RFID and sensor network. In: Kantola, J., Karwowski, W. (Eds.), Knowledge Service Engineering Handbook. CRC Press, Boca Raton, FL, pp. I87196.

THE INTERNATIONAL AIR CARGO ASSOCIATION. (1998). The TIACA Manifesto. TIACA, Miami.

THOMPSON, B. (2007). Ground handling opportunities for airports. Journal of Airport Management, I (4), 393-397.
THOMPSON, J.F., Bishop, C.F.H., Brecht, P.E. (2004). Air Transport of Perishable Products. University of California, Oakland, CA.

TRETHEWAY, M.W., Andriulaitis, R.J. (20I0). Airport competition for freight. In Forsyth, P., Gillen, D., M $\square$ ller, J., Niemeier, H.M. (Eds.), Airport Competition: The European Experience. Ashgate Publishing, Farnham, UK, pp. I37-I50.

VICTORIAN AIR FREIGHT COUNCIL. (1997). A Guide for International Air Freight Users. Business Victoria, Melbourne, Australia.

WHALEN, B. (1984). Perishable cargo delivered jet fresh by air. SAE Technical Paper 8407/4, http://papers.sae. org/8407/4/ [Accessed January 12, 2014].

WATERS, W. (20|3a). Standard procedure. Cargo Airports \& Services, March, 22-27.

WATERS, W. (20|3b). The right medicine, Cargo Airports and Services, (Autumn/Winter): 56-60.

WILLIAMS, P. (2010). Optimization of 2-8 degrees celsius controlled-temperature small parcels. http://pharmaceuticalcommerce.com/special_ report?articleid=2005 [Accessed December 19, 20।3].

WOOD, D.F., Barone, A., Murphy, P., Wardlow, D.L. (1995). International Logistics. Chapman \& Hall, New York.

YIN, R.K. (2009). Case Study Research Design and Methods (I0th ed.). SAGE Publications, Thousand Oaks, CA. 